\section{Література}

1. Кременя, В. Г. Освіта дорослих : енциклопедичний словник [Текст] / за ред. В.Г. Кременя, Ю.В. Ковбасюка. - Нац. акад. пед. наук України, Нац. акад. держ. упр. при Президентові України. - К. : Основа, 2014. - 496 с.

2. Зінчук. Н. Організаційно-педагогічні засади формування аналітичної компетентності майбутніх менеджерів у ВНЗ [Текст] / Н. Зінчук // Імідж сучасного педагога. 2010. - № 2 (101). - C. 42-46.

3. Lester, S. Professional standarts, competence and capability [Text] / S. Lester // Higher Education, Skills and Workbased Learning. - 2014. - Vol. 4, Issue 1. - P. 31-43. doi: 10.1108/heswbl-04-2013-0005

4. Shavelson, R. J. On the measurement of competency [Text] / R. J. Shavelson // Empirical Research in Vocational Education and Training. - 2010. - Vol. 2, Issue 1. - P. 41-63.

5. Маслов, В. І. Наукові основи та функції процесу управління загальноосвітніми навчальними закладами : навч. посіб. [Текст] / В. І. Маслов. - Тернопіль, Астон, 2007. - C. $126-143$.

6. Сльникова, Г. В. Компетентнісний підхід до моделювання професійної діяльності керівника ВНЗ [Текст] / Г. В. Сльникова // Теорія і методика управління освтою. 2010. - № 4. - Режим доступу: http://archive.nbuv.gov.ua/ejournals/ttmuo/2010_4/10elneel.pdf

7. Чміль, А. І. Підготовка керівника навчального закладу до управлінської діяльності в ринкових умовах : навч. посіб. [Текст] / А. І. Чміль, В. І. Маслов, Г. А. Дмитренко, Г. В. Єльникова, Г. В Федоров. - К.: Логос, 2006. - 128 с.

8. Буган, Ю. В. На допомогу менеджеру освіти. Частина VIII. Сучасний керівник навчального закладу - мене- джер освіти [Текст] / Ю. В. Буган, А. Й. Романюк, О. В. Козловська. - Тернопіль: Астон, 2003. - 344 с.

\section{References}

1. Kremenya, V. G., Kovbasuka, U. V. (2014). Adult Education Encyclopedic Dictionary Kyiv, Ukraine: Osnova, 496.

2. Zinchuk, N. A. (2010). Organizational and pedagogical principles forming the analytical competence of managers in universities. The image of the modern teacher, 2 (101), 42-46.

3. Lester, S. (2014). Professional standarts, competence and capability. Higher Education, Skills and Work-based Learning, 4 (1), 31-43. doi: 10.1108/heswbl-04-2013-0005

4. Shavelson, R. J. (2010). On the measurement of competency. Empirical Research in Vocational Education and Training, 2 (1), 41-63.

5. Maslov, V. I. (2007). Scientific principles and functions of management process secondary schools: tutorial. Ternopil, Ukraine: Aston, 126-143.

6. Elnikova, G. V. (2010). Competence approach to the professional activity modeling of the Universities leaders. Theory and methodics of educational management, 4. Available at: http://archive.nbuv.gov.ua/e-ournals/ttmuo/2010_4/10elneel.pdf

7. Chmil, A. I., Maslov, V. I., Dmitrenko, G. A., Elnikova, G. V., Fedorov, G. V. (2006). Training of education institutions leaders for management in market conditions: tutorial. Kyiv, Ukraine: Logos, 128.

8. Bugan, U. V., Romanuk, A. I., Kozlovska, O. V. (2003). To assist the manager of education. Part VIII. The modern head of the education institution is a manager of education. Ternopil, Ukraine, 344.

Рекомендовано до публікащії д-р пед. наук Рябова 3. В. Дата надходження рукопису 24.03.2015

Зінчук Наталія Анатоліївна, кандидат педагогічних наук, доцент, кафедра менеджменту освіти, економіки та маркетингу, ДВНЗ «Университет менеджменту освіти», вул. Артема, 52-А, м. Київ, Україна, 04053

E-mail: znamail@ukr.net

\author{
УДК 378.637:378.147:004 \\ DOI: 10.15587/2313-8416.2015.41398
}

\title{
THE EFFICIENCY OF THE "FLIPPED CLASSROOM" TECHNOLOGY IN THE LECTURERS TEACHING PROCESS
}

\section{(C) N. Prykhodkina}

The concept of the flipped classroom which is described in the article is based on the ideas of active learning, students' occupation in the general activity, combined learning system, podcast. The flipped classroom is important because the learning time is used for a group study, where the students can discuss the contents of a lecture, check their knowledge and interact with each other practically

Keywords: "flipped classroom", flipped class, information and communication (ICT) study, Internet, video lecture

Поняття переверненого навчання, розглянуте у статті, спирається на такі ідеї, як активне навчання, залучення студентів у загальну діяльність, комбіновану систему навчання, підкаст. Цінність перевернених класів у можливості використовувати навчальний час для групових занять, де студенти можуть обговорити зміст лекиї, перевірити свої знання й взаємодіяти один з одним у практичній діяльності

Ключові слова: «перевернене навчання», перевернений клас, інформаційно-комунікаційні технологї̈ навчання, Інтернет, відеолекція

\section{Introduction}

The modern learning process main requirement is to make the students more active. It helps to form their active lifestyle, independence, interest in a subject, to make their knowledge and skills better. The strategies and directions of the radical educational changes are clearly defined in National development strategy of education in Ukraine for the period up to 2021, the laws of 
Ukraine "on Education" and "on Higher Education", the National Program of Informatization of Ukraine, where the development of education based on the modern pedagogical concepts, the establishment of the personal and operational pedagogical technologies, especially the ICT studies, in the educational process of higher educational establishments are emphasised.

\section{Problem}

The higher educational reform leads to the development of the distance education concept, which provides the development of different technologies, including a blended learning. The blended learning means an educational technology, which is realized in combination of the full-time and electronic education. This is a "blending" of the class-and-lesson system and modern digital education. The most famous form of the blended learning is a flipped classroom.

\section{Literare review}

The researches about the ICT study usage by the lecturers are described in the works of V. Bykova, L. Zabrodska, O. Yelnykova, L. Liakhotska, V. Oliinyk and other. The implementation of the "flipped classroom" technology in the training process was investigated by such researches as D. Berhman, K. Buhaichuk, O. Yelnykova, M. Kurvits, E. Popov, A. Sams and other [1-3].

\section{The efficiency of the "flipped classroom" technology in the lecturers teaching process}

During the lectures the students often try to apprehend all the material they hear. They have no possibility to stop and think the information over, because they can miss some important things. That is why they try to write down the lecture. The students, who possess a wide range of computer skills, want and can use them while learning the new subjects. The video and other data medium let the students have an absolute control over the lecture. They can watch, rewind or fast it forward the way they need.

The flipped classroom is a pedagogical model, which provides the lecture presentation and home task organisation in reverse. At home the students watch the short video lectures and during the class they do the exercises, discuss the projects and have some disputes. The video lectures are often considered as the key component in the flipped approach. Such lectures are recorded by the lecturers and uploaded to the Internet or kept in some on-line file sharing storage. The accessibility to the video is so spread nowadays that it can be made an integral part of the flipped classroom concept [2].

The authors of the "flipped class" model of teaching are the chemistry teachers Aaron Sams and Jonathan Bergmann. In 2008 they started to record their lectures and "flip" them to homework. Aaron Sams thinks that in the classroom the students should not just get the theory, but show how they can apply the knowledge, which they have got from the video at home.

In their book "Flip Your Classroom: Reach Every Student in Every Class Every Day" they point out the peculiarities and possibilities of this technology.
However the scientists note, that some material is better to be given at a lecture than with a help of a video. That means, that teachers should not use the methods, which do not fulfil the contents of the material.

In 2010 Clintondale High School in Detroit, USA, put into practice the "flipped classroom" model and became the first "flipped school".

One of the examples of the new approach successful implementation is the Pennsylvania State University. Here more than thousand and a half students are successfully learning the accounting, using the "flipped classroom" technology video lectures. The students should discuss the material and apply the knowledge, which they have got after watching the video lectures.

The research of Center for Digital Education and Sonic Foundry shows that among the Internet community of Educational Exchange (Center for Digital Education) members, half of the teachers staff is already using the "flipped classroom" technology or is planning its implementation during the coming 12 months. 309 responses were taken. There are some basic reasons, why teachers prefer the "flipped classroom" model: better learning experience for the students, the accessibility of ICT, the first positive results taken. While using this model, the teachers discover the rise of the students' activity, number of discussions and development of cooperation in the classroom. They think, that the important thing is the possibility to make the learning process personalized for every student, to raise the learning efficiency and to rate the students more accurately. $69 \%$ of the interviewed think, that the most acceptable number of students in the "flipped classroom" is from 11 to 30.

The "flipped classroom" concept is based on such ideas as active learning, students' occupation in the general activity, combined learning system and of course podcast. The "flipped classroom" is important, because the learning time is used for a group study, where the students can discuss the contents of a lecture, check their knowledge and interact with each other practically. During the classes a teacher is a coach or consultant, who encourages the students to make their own researches and cooperate with each other.

In the "flipped classroom" model the role of a teacher is changed. That means, that a teacher yields his or her functions in favour of the cooperation and mutual contribution in the learning process. The students, whose function used to be the passive comprehension of the prepared material, should also change. In the "flipped classroom" model the students take more responsibility of their learning, for them to be motivated in making an experiment. The activity can be ruled by the students and the communication between them can become a determinant process driving force, which is aimed at learning with the help of practical skills. What makes the "flipped classroom" special is the shift of priorities from giving the prepared material to the work on its improvement.

Let's compare the conventional and "flipped" model of learning according to some criteria: the student's role, the teacher's role, the role of ICT in the learning process, the methods and structure used during the classes (Table 1). 
Table 1

The conventional and "flipped" models of learning comparison

\begin{tabular}{|l|l|l|}
\hline & \multicolumn{1}{|c|}{ The conventional learning } & \multicolumn{1}{c|}{ The "flipped" learning } \\
\hline Student & $\begin{array}{l}\text { Passivity, the absence of initiative and wish } \\
\text { in self studying. The working model "listen, } \\
\text { remember, retell". }\end{array}$ & $\begin{array}{l}\text { IThe students' occupation in the learning process. } \\
\text { The responsibility of the learning. The cooperation } \\
\text { with the all learning process participants. The com- } \\
\text { prehension of learning. }\end{array}$ \\
\hline ICT & $\begin{array}{l}\text { The technologies and web tools usage in the } \\
\text { learning process }\end{array}$ & The ICT working methods and forms change \\
\hline Teacher & $\begin{array}{l}\text { Giving knowledge, keeping the discipline in } \\
\text { the class, students' knowledge control }\end{array}$ & $\begin{array}{l}\text { Learning situation construction, making the stu- } \\
\text { dents to be responsible for their learning }\end{array}$ \\
\hline $\begin{array}{l}\text { The struc- } \\
\text { ture of the } \\
\text { lesson }\end{array}$ & $\begin{array}{l}\text { During the lecture in the class the students } \\
\text { teachen to the theory without any opportunity to } \\
\text { discuss it because of the time limit }\end{array}$ & $\begin{array}{l}\text { At home the students watch the video lectures with } \\
\text { a theory and discuss the problematic moments dur- } \\
\text { ing the class }\end{array}$ \\
\hline
\end{tabular}

There are many "flipped classroom" models of teaching. This term is used to describe nearly any learning structure, which is based on watching the recorded lectures with their following discussion during the class. The students can watch several 5-7 minutes lectures in one general model. During the on-line inquiry or some tasks the students can be asked to prove the knowledge they have got. Direct inquiry response and the possibility to watch a video again make it easier to understand some difficult things. The short video lectures with a theory let the students learn the material in a suitable speed, rewind to some important moments and skip the already known facts. As a result at the class the students are ready to use the software and do the creative projects with others. When analysing the material during the class, the teachers can find out the mistakes in the theory comprehension, especially the most widespread ones. In addition the common projects can make the social interaction between students better and the information perception easier.

The teachers can make discussions during the class or even turn it into a studio, where the students can interact with each other, apply the lecture theory and the other material, which they have observed outside the classroom. The teachers, as the experts in the field, set different approaches, specify the content and observe the progress. To solve the problem, which is the subject of the work for several students, the teachers can organize them into a working group. Some teachers use only several flipped classroom model of teaching elements or several flipped lectures during all the learning course.

We believe, that the "flipped classroom" model of teaching makes great use for the postal tuition students. The subjects present great deal of material. But there are only 24 contact hours or even less. It is impossible to make the students comprehend such a big deal of material and form good practical skills within the time limit by the conventional means of classical pedagogics. The teachers should search for the ways of lectures and practical courses intensification. Within the time limit the "flipped classroom" stipulates the rejection of such ineffective methods: the students' public presentations, general questioning, lecture dictation, watching the long training films and presentations. Instead the elements of cooperation pedagogics are implemented when the teacher acts as a colleague and consultant. The students comprehend the learning material themselves developing their cognitive activity and independence.

Before implementing the "flipped classroom" model of teaching you should weigh, whether it is suitable for the curriculum and the students. The critics doubt, whether the students will be receptive to the new learning ideology, whether it is possible to record the lectures in a good quality, whether the technologies are accessible to the teachers.

\section{Approbation of the research results}

During the "Innovative pedagogical technologies" course taken by the students of Higher Education Pedagogy (HEP) field, we approbated the "flipped classroom" model. As these students are getting the second degree in pedagogics and working as lecturers, they were proposed to make a creative task during the intersession period: to approbate the "flipped classroom" model in their classes. This includes making the training system project (the contents of lessons), which suits the educational standard of the subject, which they teach and make the play list of video with a theory. There are open educational resources (also in Ukrainian), where they could take the videos, so they might not record the material themselves. They could add the links to the book chapters in the play list. The electronic educational resources (EER) helped them to raise the learning efficiency. The EER is a specific educational accessory for the students' self studying. This makes them intensely active, individualizes their work and gives the opportunity to manage their cognitive activity themselves [4]. The EER combine the e-learning modules of three types: informational, practical and control. They are followed by the subject videos and interactive tasks. For the practical courses (in mathematics, physics, chemistry) the EER provide laboratory works, homework assignments and the examples of how to do the tasks.

As a technological base for the flipped classroom realisation Moodle system may be used. Moodle (Modular Object-Oriented Dynamic Learning Environment) is a regulating educational system, which is oriented on the interaction between a teacher and a student [2]. Using Moodle the teacher makes the course of lectures material, 
presentations, practical tasks, tests and pictures, diagrams, tables, links and other Internet resources. Moodle is the center of learning material making and means of interaction between a teacher and a student, where the first can always provide a help.

After the intersession period we made a survey of HEP students about the realization of flipped classroom model. The results showed mainly the positive response about the flipped classroom. $87 \%$ of students admitted, that the flipped classroom helped them to enjoy their work more, $67 \%$ said about the students' better testing results, $80 \%$ noticed the better attitude of the students towards the learning process, $99 \%$ are ready to use these forms of study elements further. In particular, the answers were the following: "this was the most serious and successful step I have made during the 11 years of working as a teacher", "the changes are appreciable and I can work with the students more effectively", "the students are really interested in working at the class", "the students asked to keep on working this way", "I have been teaching philosophy for 10 years and never seen that the students worked so assiduously and comprehended the material so well", "the flipped studying made a better possibility and efficiency in individual communication with the students", "I think, that the conventional teaching methods I will use seldom" and other.

In the context of the "flipped classroom" there arises a question: how to make the students interested in learning the forward material, if they usually do not do the home task properly. They think, that the only way of solving this problem is using the interesting, informative and understandable content in the video lessons, video lectures or books, which are used in this methodology.

But the students admit, that it is easy to make mistakes when learning according to the flipped classroom model. Though the idea is very simple, the efficient "switch" requires the diligent preparation. The lectures recording requires a lot of teachers' time, so that the classroom and extracurriculum elements look like a single unit, for the students to understand the principle of this model and to be motivated to prepare for the classes. And finally the implementation of the flipped classroom model means the additional bit of work and requires some new teachers' skills. But this process can be made easier by integrating the model gradually.

The students complain about the absence of fulltime lectures, especially knowing that the video lectures are accessible to everyone in the Internet. That is why they can not judge the practical meaning of the model. They ask, what they can get from such a learning, just browsing the Internet. Those students, who used to visit the lectures, can easily miss the practical courses, so they miss the real value of the flipped studying. Finally, even if the students appreciate this learning model their technical resources not always give the opportunity to watch a video in a good quality.

\section{Conclusions}

So, the flipped study technology gives the opportunity to change the learning approach from passive to active. As a result the students are well prepared for their future career and comprehend the material deeper. This model, as one of the mixed learning types, helps to use the teachers' and students' time efficiently.

\section{References}

1. Ahmad, I. M. Navchannya $v$ distantsiyniy i zmishaniy formi studentiv VNZ [Education of university students in Distance and mixed forms] [Text] / I. M. Ahmad. - Suchasni pidhodi ta innovatsiyni tendentsiyi u vikladanni inozemnih mov: Materiali VII Mizhnarodnoyi naukovo- praktichnoyi konferentsiyi, 2012. $-248 \mathrm{p}$.

2. Kalenskiy, A. A. Zastosuvannya pedagogichnih InformatsIynih tehnologIy u navchalnomu protsesi vischoyi shkoli [The use of information technology in teaching learning process of high school] [Text] / A. A. Kalenskiy. - Kiev, 2011. - 280 p.

3. Kurvits, M. Perevorachivaem obuchenie. Chast pervaya: predposyilki modeli obucheniya "perevernutyiy klass" [Overturn training. Part One: Background learning model "flipped classroom"] [Electronic resource] / M. Kurvits. Available at: http://blognauroke.blogspot.com/2013/09/blogpost_26.html

4. Mur, M. G. Informatsionnyie i kommunikatsionnyie tehnologii v distantsionnom obrazovanii : Spetsializirovannyiy uchebnyiy kurs [Information and communication technologies in distance education: Specialized training course] [Text] / M. G. Mur, U. Makintosh, L. Bljek. - 2006. - 632 p.

5. Prykhodkina, N. O. Vikoristannya tehnologiyi "perevernenogo navchannya" u profesiyniy diyalnosti vikladachiv vischoyi shkoli [Using "flipped-classroom" in professional work of teachers of high school] [Text] / N. O. Prykhodkina // Naukoviy visnik Uzhgorodskogo natsionalnogo universitetu: Seriya: "Pedagogika. Sotsialna robota". 2014. - Vol. 30. - P. 141-144.

6. Hallberg, S. An Alternate Approach in the Application of the Thayer Concept of Teaching [Electronic resource] / S. Hallberg. - Available at $\backslash$ : https://web.archive.org/ web/20140204024004/http://www.usma.edu/cfe/Literature/SHa llberg_10.pdf

7. Ribeiro, R. Q. Flipped Classroom Pioneer, Reflects on His Journey [Electronic resource] / R. Q.Ribeiro, A. J. Bergmann. - Available at: http://www.edtechmagazine. com/k12/article/2013/11/qa-jon-bergmann-flipped-classroompioneer-reflects-his-journey

8. What Is Flipped Learning? [Electronic resource] / Availableat: http://flippedlearning.org/cms/lib07/VA01923112/ Centricity/Domain/46/FLIP_handout_FNL_Web.pdf

\section{References}

1. Ahmad, I. M. (2012). Navchannya v distantsiyniy i zmishaniy formi studentiv VNZ [Education of university students in Distance and mixed forms]. Suchasni pidhodi ta innovatsiyni tendentsiyi u vikladanni inozemnih mov: Materiali VII Mizhnarodnoyi naukovo-praktichnoyi konferentsiyi, 248.

2. Kalenskiy, A. A. (2011). Zastosuvannya pedagogIchnih InformatsIynih tehnologIy u navchalnomu protsesI vischoYi shkoli [The use of information technology in teaching learning process of high school], 280.

3. Kurvits, M. Perevorachivaem obuchenie. Chast pervaya: predposyilki modeli obucheniya "perevernutyiy klass" [Overturn training. Part One: Background learning model "flipped classroom"]. Available at: http://blognauroke.blogspot. com/2013/09/blog-post_26.html

4. Mur, M. G., Makintosh, U., Bljek, L. (2006). Informatsionnyie i kommunikatsionnyie tehnologii v distantsionnom obrazovanii: Spetsializirovannyiy uchebnyiy kurs [Information and communication technologies in distance education: Specialized training course], 632.

5. Prykhodkina, N. O. (2014). Vikoristannya tehnologiyi "perevernenogo navchannya" u profesiyniy diyalnosti vikladachiv vischoyi shkoli [Using "flipped-classroom" in 
professional work of teachers of high school]. Naukoviy visnik Uzhgorodskogo natsionalnogo universitetu: Seriya: "Pedagogika. Sotsialna robota", 30, 141-144.

6. Hallberg, S. An Alternate Approach in the Application of the Thayer Concept of Teaching. Available at: https://web.archive.org/web/20140204024004/http://www.usma. edu/cfe/Literature/SHallberg_10.pdf
7. Ribeiro, R. Q., Bergmann, A. J. Flipped Classroom Pioneer, Reflects on His Journey. Available at : http://www.edtechmagazine.com/k12/article/2013/11/qa-jonbergmann-flipped-classroom-pioneer-reflects-his-journey

8. What Is Flipped Learning? Available at: http://flippedlearning.org/cms/lib07/VA01923112/Centricity/ Domain/46/FLIP_handout_FNL_Web.pdf

Рекомендовано до публікачії д-р пед. наук, професор Рябова 3. В. Дата надходження рукопису 27.03.2015

Prykhodkina Nataliya, PhD, Associate Professor, Department of Management and Pedagogy of higher school, State Higher Educational Institution "University of Educational Management" of National Academy of Pedagogical Sciences of Ukraine, st. Artema, 52a, Kyiv, Ukraine, 04053

E-mail: prykhodkinanataliya2012@gmail.com

УДК 378: 005.915

DOI: $10.15587 / 2313-8416.2015 .41159$

\section{ОРГАНІЗАЦІЙНО-ПЕДАГОГІЧНІ УМОВИ ДІЯЛЬНІСТЬ КЕРІВНИКІВ ВИЩИХ НАВЧАЛЬНИХ ЗАКЛАДІВ: ФІНАНСОВИЙ МЕНЕДЖМЕНТ}

\section{(C) Л. Золотокотська}

У статті досліджено організачійно-педагогічні умови управлінської діяльності керівників ВНЗ на основі ФМ; обтрунтовано актуальність проблеми ефективної реалізації фінансового менеджменту керівниками ВНЗ (необхідність розв'язання суперечностей, наявність сочіально-економічних зрушень, а також вимоги теорії і практики управління освітою); досліджено теоретичні та практичні аспекти зазначеної тематики з метою вдосконалення науково-методичних підходів до реалізації фінансового менеджменту керівниками ВНЗ тощяо

Ключові слова: керівники вищих навчальних закладів, фінансовий менеджмент, організаційнопедагогічні умови, ефективність

The article deals with pedagogical conditions of management of university heads based on FM; reasonably relevance of effective implementation of financial management by heads of universities (necessity of resolving contradictions, the presence of the socio-economic changes and the requirements of the theory and practice of educational management ); the theoretical and practical aspects into the issue in order to improve the scientific and methodological approaches to the implementation of financial management in universities

Keywords: heads of universities, financial management, organizational and pedagogical conditions, efficiency

\section{1. Вступ}

Шлях європейської та світової інтеграції, обраний Україною, зумовлює необхідність інтенсивних змін у різних сферах суспільного життя, зокрема й у галузі вищої освіти (далі - ВО). У Національній доктрині розвитку освіти проголошено орієнтацію на новий тип гуманістично-інноваційної освіти, що означає перехід до нововведень як способу існування системи, що продукує сама вища школа та який слугує основою ії цілеспрямованого, контрольованого й керованого розвитку. Подолання особливостей об'єктивно існуючої ситуації потребує обтрунтування теоретичних і методичних засад ефективної реалізації функцій вишівського менеджменту (далі- ВМ) i в його межах тих функцій, які належать до фінансового напряму діяльності ВНЗ як багатоаспектної відкритої цілісної реальності наукового пошуку.

Основними напрямами вирішення сучасних проблем освіти, на нашу думку, є: вдосконалення нормативної бази; розроблення концептуальних засад розвитку освітнього менеджменту, зокрема вузівсь- кого; вдосконалення управління ВНЗ шляхом ефективної реалізації функцій ВМ керівниками ВНЗ (багатоаспектності та багатоформатності їх реалізації; виявлення організаційно-педагогічних умов реалізації функцій ФМ; формування готовності керівників ВНЗ до ефективної реалізації управлінських функцій в напрямі розв'язання проблем фінансової сфери діяльності тощо).

\section{2. Актуальність і постановка проблеми дос-} лідження

Актуальність теми авторського дослідження обумовлена тим, що Україна поступово крокує шляхом, що зумовлений посиленням інтеграційних процесів із Свропою, відродженням національної культурної спадщини, змінами в економічних процесах. Трансформація України як незалежної суверенної держави потребує від іiї політичної, громадської, науково-педагогічної спільноти створення оптимальних умов для розвитку особистості та прогресу суспільства, які забезпечують індивідуальний розвиток май- 